\title{
A RECEPÇÃO DA CRÔNICA O “MINEIRINHO”, DE CLARICE LISPECTOR, POR JOVENS LEITORES DO ENSINO MÉDIO ${ }^{1}$
}

\author{
Licenciando: Israel José da Silva ${ }^{2}$ \\ Orientador: Clecio dos Santos Bunzen Júnior (DMTE-CE)
}

\begin{abstract}
Resumo:
Este trabalho de conclusão de curso tem como objetivo analisar e discutir a recepção do texto literário por leitores em formação de uma turma de terceiro ano do Ensino Médio da Escola de Referência Albertina da Costa Soares, na cidade do Ipojuca. Para isso, usamos a crônica "Mineirinho", da escritora Clarice Lispector, em um Círculo de leitura, método aplicado e discutido por Cosson (2014), permitindo, assim, que o contato do leitor com o texto literário e a sua compreensão reflexiva da leitura feita fossem "livre" de qualquer pergunta ou teoria que buscasse moldar a sua reflexão. Os comentários dos leitores ao texto após a leitura foram analisados e discutidos sob a luz do referencial teórico de COSSON (2014), CEREJA (2004), EAGLETON (2006), ALVES (2014), AGAZZI (2014), FREDERICO \& OSAKABE (2004), BARBOSA (2011), OLIVEIRA (2010), ROUXEL (2014), BRASIL (2006), ZILBERMAN (2012; 2017), CANDIDO (2014), SILVA (2005), LANGLADE (2013), ROSENBAUM (2010), KAHN (2000), ou seja, discussões, no geral, que buscam discutir a presença da obra literária e sua leitura em sala de aula. Como resultado de pesquisa deste trabalho pudemos analisar e discutir a falta de uma leitura reflexiva mais profunda do texto literário como causa de um ensino da Literatura excludente, arcaico e tecnicista, baseado no método de memorização e repetição de informações.
\end{abstract}

Palavras-chave: Literatura. Recepção. Formação do leitor.

\begin{abstract}
This final degree project aims to analyze and discuss the reception of the literary text by readers in development of a classroom of a senior year of high school at the Reference School Albertina da Costa Soares in the city of Ipojuca. For this, we use the text "Mineirinho", by the writer Clarice Lispector, in a Reading Circle, method applied and discussed by Cosson (2014), thus allowing the reader's contact with the literary text and their reflective comprehension of the reading done in the class would be free of any question or theory that tried to shape their reflection. The readers' comments on the text after its reading were analyzed and discussed by the guidance of studies/reseach of authors as COSSON (2014), CEREJA (2004), EAGLETON (2006), ALVES (2014), AGAZZI (2014), FREDERICO \& OSAKABE (2004), BARBOSA (2011), OLIVEIRA (2010), ROUXEL (2014), BRAZIL (2006), ZILBERMAN (2012; 2017), SILVA (2005), LANGLADE (2013), ROSENBAUM (2010), KAHN (2000), who aim to discuss, in general, the litarery text presence and its reading practice in the classroom. As a result from this research, we were able to analyze and discuss the lack of a deeper reflective reading of the literary text as the cause of an exclusionary, archaic and technicist literary teaching based on the method of memorization and repetition of information.
\end{abstract}

Key-words: Literature; Reception; Readers development.

\section{INTRODUÇÃO}

Esta pesquisa foi desenvolvida a partir das experiências vivenciadas nas disciplinas de Estágios supervisionados em Língua Portuguesa, pela Universidade Federal de Pernambuco. No total, foram quatro Estágios - distribuídos entre observação e regência -, porém, o que mais despertou meu interesse como pesquisador e professor em formação foi a experiência vivida na observação de uma turma do Ensino Médio, em que pude verificar nas aulas de

\footnotetext{
1 Trabalho de Conclusão de curso em Letras-Português, 2018, da disciplina TCC II, sob a avaliação dos professores Clecio dos Santos Bunzen Júnior e Janaína Ângela da Silva.

${ }^{2}$ Graduando em Letras-Português pela Universidade Federal de Pernambuco.
} 
Literatura ministrada pelo professor da escola-campo uma metodologia do conteúdo literário - defendida por Cereja (2004) como sendo a causa do "fracasso" escolar em não conseguir formar leitores autônomos e críticos ao fim da última etapa do Ensino médio - que se respalda na transmissão e repetição de informações específicas e decoráveis sobre a obra literária, o autor e o contexto sociopolítico de publicação do texto. A leitura, enquanto eixo a se desenvolver do Letramento Literário, era posta em segundo plano e se restringindo à localização nos fragmentos dos textos das informações passadas pelo docente ao longo da aula.

Dessa forma, surgiu o interesse em analisar através de um Círculo de leitura os efeitos da prática docente - a metodologia do ensino da Literatura por ele desenvolvida -, observada na disciplina de Estágio supervisionado II, sobre os alunos, enquanto leitores em formação. Para uma melhor compreensão, dividimos esta pesquisa em três partes, a primeira se volta a uma breve contextualização histórica do ensino literário, a segunda discute a importância da leitura literária e do professor enquanto mediador entre o texto e o leitor e, por fim, a terceira parte traz o resultado da pesquisa, apresentando as leituras desenvolvidas sobre a crônica "Mineirinho" e as nossas análises e reflexões diante de cada posicionamento dos leitores em relação ao contato com o texto.

Buscamos como aporte teórico estudos de COSSON (2014), CEREJA (2004), EAGLETON (2006), ALVES (2014), AGAZZI (2014), FREDERICO \& OSAKABE (2004), BARBOSA (2011), OLIVEIRA (2010), ROUXEL (2014), BRASIL (2006), ZILBERMAN (2012; 2017), SILVA (2005), LANGLADE (2013), ROSENBAUM (2010), KAHN (2000). Teorias e estudos, estes, que visam a analisar e discutir a importância da leitura literária, da presença do texto em sala de aula, do professor enquanto mediador e dos alunos (leitores em formação) como um componente ativo no processo de ensino-aprendizagem. Debruçamo-nos igualmente sobre estudiosos da obra da escritora Clarice Lispector buscando compreender a singularidade dos seus textos.

\section{A FrAgmentaÇÃo do TEXTO Literário EM SALA DE AULA NO ENSINO DE LITERATURA}

Desde a democratização do chamado ensino secundário em meados da década de 60, as escolas públicas passaram a ser frequentadas não apenas por adolescentes pertencentes à alta burguesia, que compartilhavam, basicamente, as mesmas experiências socioculturais e o 
mesmo dialeto, mas também por jovens oriundos de diferentes classes sociais, com experiências linguísticas e culturais diversas (cf. FREDERICO; OSAKABE, 2004). Diante dessa abertura do ensino secundário ao público, agora sem restrição à classe social, as escolas se viram despreparadas para a quantidade e diversidade dos alunos. Elas, portanto, tiveram de improvisar a mão de obra docente, visto que muitos professores foram formados às pressas ou sem qualificação necessária para desenvolver tal função (cf. CEREJA, 2004).

A partir de então, o ensino da Literatura em sala de aula, que antes era feito com o auxílio de uma antologia de textos literários, foi condensado no manual didático, de forma que o estudo da gramática da Língua Portuguesa e Literatura dividiam e ainda dividem o mesmo espaço, embora separados por sessões. Estes manuais, segundo Cereja (2004), traziam perguntas superficiais e informações datadas sobre o texto, buscando atender ao novo perfil de professor e de alunos sobrecarregados, pois muitos desses alunos eram matriculados no curso noturno porque trabalhavam durante o dia. Outro ponto importante era a relevância dada à vida do autor e a qual movimento literário a obra pertencia como meio de se compreender o texto literário.

A má formação de professores, as suas péssimas condições de trabalho, a má organização de um material didático que visasse à construção de conhecimento críticoreflexivo dos alunos deve-se, segundo Cereja (2004), "ao fracasso da escola" em não conseguir formar leitores competentes. Somam-se ainda à causa deste fracasso escolar as influências dos primeiros exames de pré-vestibular no ensino de literatura, que foram tornando-se cada vez mais um ensino da história da Literatura com informações topicalizadas e exteriores ao texto literário (ZILBERMAN, 2012).

Tanto os livros didáticos quanto os exames de vestibular, assim como o ENEM, por exemplo, têm promovido uma "relativa mudança" na forma como apresentam o conteúdo literário, modificando assim, também, o ensino da Literatura na escola (CEREJA, 2004). No entanto, ainda é a metodologia historicista da literatura que permeia a prática docente em sala de aula e em alguns livros didáticos de português.

Esta metodologia da literatura, que ainda ecoa no contexto escolar, toma o texto literário, quase sempre de forma fragmentada. O texto, ou o fragmento dele, serve então de pretexto para se discutir questões relacionadas à gramática da língua - uma concepção arcaica de que o texto literário seria o padrão de língua a ser aprendido (SILVA, 2005). Além disso, busca-se, também, trazer para a "discussão e apreciação da obra", principalmente em Livros didáticos de Português, um breve resumo da vida do (a) autor (a), com um parágrafo 
informando sobre suas principais características de escrita e a qual período da cronologia da história da Literatura ele faz parte. E, para encerrar a "análise" do texto em sala de aula, o (a) professor (a) fala do contexto social de produção do texto literário. Sobre isso, acrescenta ainda Rouxel (2014, p. 20):

(...) na realidade das aulas do ensino básico e mesmo, às vezes, na educação infantil, a leitura exigida repousa sobre uma série de observações formais que entravam o investimento pessoal do leitor. O texto lido e estudado é quase sempre um pretexto à descoberta e aquisição de ferramentas de análise e, então, objeto de uma rotina desencarnada que deixa "fora de jogo" o leitor enquanto sujeito. Os alunos não leem mais, eles aprendem a identificar o jogo de focalizações, o estatuto do narrador intra ou extradiegético, o discurso indireto livre, as figuras de estilo; eles elaboram o esquema actancial sem exprimir seu julgamento sobre tal ou tal personagem etc.

Dessa forma, nega-se o texto integral e sua leitura em sala de aula, assim como a possibilidade de construção de sentidos por meio do contato dialógico reflexivo entre o livro e os jovens leitores, privando e excluindo o aluno da leitura.

Foi pensando nesse "modelo de aula expositivo que ainda impera no ensino de literatura no nível médio e na universidade" (ALVES, 2014. p. 09) que procuramos desenvolver um círculo de leitura para trabalhar a recepção do texto literário em sala de aula, na qual, de acordo com preceitos da teoria da Estética da Recepção, o foco da aula de literatura poderia ser o leitor, como afirma Zilberman (2017, p. 23-24):

\footnotetext{
Não que ao leitor seja atribuída muita autonomia para exercer o protagonismo que lhe é transferido, pois são elementos textuais - presentes e ausentes, como indeterminações e lacunas - que acionam as tais disposições e, sobretudo, sua imaginação. Assim, o que o leitor faz é "atualiza[r] o potencial implícito no texto." (ISER, 1975, p. 258 apud ZILBERMAN, 2017, p. 23-24); mas, ainda assim, trata-se de uma ação que o valoriza, pois reconhece que, sem sua interferência, o texto literário corresponde a um ser sem vida.
}

O leitor ressignifica o texto a partir da sua leitura e experiência de mundo (EAGLETON, 2006). Portanto, dá-se a importância da leitura integral ou fragmentada dos textos literário em sala de aula, porém, visando sempre o desenvolvimento do hábito e de habilidades de leitura, das reflexões sobre a obra literária em si e sobre as realidades existentes ou possíveis presentes no ato da leitura.

Dessa forma, buscando uma abordagem do conteúdo literário em sala de aula mais flexível, o professor poderia incluir entre os cânones literários, livros de autores contemporâneos e da chamada literatura de massa. Assim, os jovens leitores teriam a oportunidade de sugerir obras que fizessem parte de sua realidade, e caberia ao mediador incentivar a leitura dos clássicos através dos temas sugeridos - um estudo comparativo, por exemplo -, lidos e discutidos em sala. 
Pois o que se propõe é autonomia para o leitor, rompendo do contexto escolar público a visão preconceituosa de que os alunos não são capazes de acessar informações, além daquelas que estão dispostas na superfície do texto. Portanto, racionalizaram a literatura em períodos (escolas literárias), forçando autores e obras a pertencerem a determinado período literário, no qual cada um teria suas características de produção de escrita já pré-determinadas, facilitando, supostamente, para o aluno-leitor a apreensão do conteúdo literário (FREDERICO; OSAKABE, 2004).

É, portanto, diante da resistente prática dessa metodologia de ensino nas aulas de literatura e de leitura literária, a qual subestima a capacidade do aluno de ter acesso à compreensão do texto literário por motivos formais ou estilísticos (COSSON, 2014), que se propõe um novo modelo de ensino da literatura brasileira e estrangeira. Desta forma, a leitura e a análise interpretativa são o ponto principal, mesmo que sejam feitas por meio de fragmentos da obra, da metodologia aqui trabalhada. Assim, o que propomos é uma análise mais crítica sobre um discurso historiográfico da literatura, para o qual o contexto social de publicação da obra e a vida do escritor são tomados como as características mais importantes na hora da análise e discussão do texto literário.

Não negamos haver textos em que, para se ter acesso à determinadas informações que irão somar significados na construção de sentidos ao longo da leitura é necessário a análise e discussão do contexto social em que foram escritos, assim, é igualmente importante, até certo ponto, saber dados biográficos do autor da obra. Por exemplo, em alguns textos do Jorge Amado (1912 a 2001), escritor baiano, que escreveu em um período sócio-político específico, diferente do que se vive hoje no século XXI. É possível notar que as informações acerca da política e do meio social do qual o autor viveu fortemente encontram-se "imersas" em suas obras.

É importante ressaltar que o ensino de literatura não está, ou não deveria estar, focado em fazer com que os alunos decorem dados históricos, como data e ano de publicação da obra, a qual estética literária ela pertence, o que estava ocorrendo naquele período em relação ao contexto social, ou questões biográficas do autor (BARBOSA, 2011; COSSON, 2010). Espera-se, por outro lado, que o ensino de literatura provoque a reflexão e discussão de temas diversos por meio da leitura das obras literárias, e o professor possa ser um mediador entre o texto e o leitor-aluno.

Conforme Cereja (2004), conceitos da teoria da comunicação também foram aderidos às análises dos textos literários dentro do contexto escolar, tornando a experiência da leitura e 
análise literária ainda mais mecanizada e destituída de sentido prático. Como resultado desenvolveu-se uma metodologia de ensino da literatura que põe o texto em posição periférica nas aulas de leitura literária, priorizando o ensino de informações "decorebas" acerca do texto e uma cronologia de estudo dos movimentos literários, ressaltando de cada movimento, ou escola literária, seus principais autores. Autores estes que já foram cristalizados pela crítica canônica, fazendo-se, então, um panorama das suas características de escrita e dos seus outros títulos já publicados, seguido de um breve resumo de sua obra supostamente mais importante, e por fim, exercícios que não exigem dos alunos habilidades de leitura, apenas a capacidade de localizar informações superficiais no texto.

Acrescenta-se ainda o fato de que uma leitura unicamente fragmentada e artificial do texto literário produz uma compreensão fragmentada e artificial. É preciso que o professor e a professora levem com frequência o texto integral para a sala de aula transformando a aula sobre a história da literatura em aula de leitura literária. Porém, para que isso aconteça, é necessário que "ele próprio seja um usuário assíduo da literatura" (OLIVEIRA, 2010. p. 52).

Mas ainda é preciso, e talvez seja o mais importante, que as leituras sejam baseadas nas experiências de leitura pessoal de cada leitor ou que no texto aborde uma realidade próxima a (d)eles, incluindo-os na leitura. Pois de nada adiantaria levar grandes nomes da literatura nacional ou internacional se os alunos não se interessarem em lê-los ou entenderem a leitura proposta como imposição, tornando-a um suplício.

No entanto, a questão talvez não seja ensinar ou não os clássicos, e sim, como ensinálos, uma vez que, de acordo com Silva \& Martins (2010, p. 25, grifo nosso):

\footnotetext{
$O$ contato com os clássicos, o leitor tem a possibilidade de conhecer e compartilhar das diferentes dimensões da experiência humana, dos imaginários de outros povos e de outras épocas, mesmo sem nunca tê-los vivenciado. De tal modo, a leitura dos clássicos confere aos leitores a possibilidade de enxergar a realidade de maneira ampliada, para além de seu restrito meio social, o que podemos definir como experiência de leitura.
}

Foi considerando a importância dos clássicos na formação humanística dos jovens leitores que pensamos para este trabalho a leitura da crônica Mineirinho, da escritora Clarice Lispector.

No entanto, torna-se importante o trabalho com títulos sugeridos pelos alunos como uma iniciação à leitura (literária), e, a partir desses títulos o professor poderá dentro da temática indicar alguns dos clássicos para compor a "lista" de leitura. Sendo assim, é necessário que o professor escute aos seus leitores, conheça-os (de onde vem, qual o contexto 
sociopolítico deles), pois torna menos complicada a tarefa de ele mesmo sugerir títulos para a leitura. Como afirma Silva (2005, p. 21):

O professor precisar realizar a seleção de textos literários, tendo em vista os interesses e a capacidade interpretativa dos alunos. (...) Além disso, é essencial que o aluno tenha a liberdade de selecionar seus próprios textos, a partir de suas experiências prévia de leitura, no sentido de descobrir o prazer de ler.

Isso nos leva a acreditar que um dos grandes problemas nas aulas de literatura seja a falta de sentido nas leituras dos fragmentos feitas em sala de aula, e, a exclusão do leitor-aluno como personagem fundamental no processo de (re)ssignificação do texto literário.

É assumindo a importância do (a) aluno (a) nas aulas de leitura literária como um indivíduo social e historicamente situado, que pensamos esse trabalho como forma de discutir, incentivar e elaborar um novo caminho para o (a) professor (a) de Português trabalhar a Literatura e a leitura literária em sala de aula deixando um pouco de lado a velha tradição do ensino da História da Literatura. Assim como desejo de devolver ao texto literário o direito de ser lido integralmente - quando possível - e discutido em sala de aula, compreendemos que se deve mesclar a discussão reflexiva ora com elementos do próprio texto ora com o ponto de vista do aluno-leitor sobre o texto.

\section{A IMPORTÂNCIA DA LEITURA LITERÁRIA E DO PROFESSOR ENQUANTO MEDIADOR}

O contato com o texto literário dentro ou fora da escola tende a transmitir alguns valores socialmente construídos ao longo do tempo. Tais reflexões podem provocar questionamentos em torno da existência humana refletindo-as no seu dia a dia, uma vez que o leitor se percebe pertencente a um grupo social e que desenvolve um papel sociopolítico. Acreditamos, portanto, que o contato com a literatura pode humanizar aquele que a abraça de corpo e alma:

\footnotetext{
Entendo aqui por humanização [...] o processo que confirma no homem aqueles traços que reputamos essenciais, como o exercício da reflexão, a aquisição do saber, a boa disposição para com o próximo, o afinamento das emoções, a capacidade de penetrar nos problemas da vida, o senso da beleza, a percepção da complexidade do mundo e dos seres, o cultivo do humor. A literatura desenvolve em nós a quota de humanidade na medida em que nos torna mais compreensivos e abertos para a natureza, a sociedade, o semelhante (CANDIDO, 2014, p. 29).
}

No entanto, como desenvolver a leitura crítica e reflexiva com os jovens leitores se o trabalho feito com o texto literário em sala de aula se reduz a um discurso historiográfico da 
literatura, como já foi aqui exposto, ou a temas exteriores à obra, como por exemplo, o estudo da gramática por si só?

Portanto, o que se espera de um aluno ao fim do terceiro ano do ensino médio é que ele possa articular alguns saberes da língua materna com naturalidade, ultrapassando a simples tarefa de decodificação dos textos. Por meio das aulas de literatura e leitura literária que tiveram ao longo da sua formação no ensino médio, esses jovens leitores deveriam ser capazes de perceber elementos estilísticos e estruturais básicos que auxiliam na construção de sentidos do texto. Assim como levantar questionamentos, fazer comparações, inferir, e perceber, por exemplo, o uso de uma ironia, dentro do próprio texto ou referencial (CEREJA, 2004).

Para que a escola cumpra seu papel de formar leitores críticos e reflexivos (BRASIL, 2006), é necessário que o professor esteja engajado com a leitura (literária) e em provocar nos alunos o interesse pela leitura rompendo com o velho modelo metodológico do ensino sobre a Literatura. Para este modelo o professor não precisa ser de fato um leitor, e sim que conheça a história da Literatura e que seja capaz de seguir a lista de livros sobre os quais deve apresentar, resumir, identificar o (a) autor (a), suas principais características de escrita, as outras obras que ele (ela) já publicou e o breve resumo bibliográfico do (a) autor (a).

O foco dessa metodologia desenvolvida pela maioria dos professores de Português, conforme Cereja (2004), parece estar bastante ligado à (re)produção de informações topicalizadas para se responder, inicialmente, às provas da escola, que são réplicas de questões das provas de vestibulares das universidades. Isso porque não parece haver preocupação em trabalhar nos jovens leitores as habilidades de leitura, e sim, principalmente nos anos finais do ensino médio, fórmulas prontas para se responder a determinada pergunta e os chamados "bizus", quando o discurso de ingressar em uma universidade toma conta das salas de aula.

Segundo Orientações Curriculares Nacionais para o Ensino Médio (BRASIL, 2006), neste modelo de aula parece não haver espaço para a subjetividade da leitura em sala de aula, principalmente quando o gênero é o poema. "Sabe-se que ela - a poesia - tem sido sistematicamente relegada a um plano secundário. Muito já se falou sobre a dificuldade de lidar com o abstrato, com o inacabado, com a ambiguidade, características intrínsecas do discurso poético" (BRASIL, p. 74). Optando-se por outros gêneros, os quais possam ser mais bem definidos em termos de informações concretas, como por exemplo, saber qual o tipo e o sexo do narrador do texto, quantos narradores existem, em qual momento se passa 
determinada história, etc. São questões que ajudam na compreensão do texto, mas para isso ele deve ser lido, integralmente, e discutido com reflexões envolvendo outros aspectos, além dos estruturais.

O conto ou o romance parecem atender melhor esse modelo didático anti-subjetivo se comparado ao trabalho com o poema -, que prioriza o trabalho sobre a história da literatura em detrimento da leitura literária. De acordo com (BARBOSA, 2011. p. 154-155), "trabalhar efetivamente para a formação de leitores de literatura significa construir práticas centradas na produção de leituras 'protagonizadas' pelos alunos". E como já foi visto anteriormente, desde a democratização do ensino secundário a escola parece não saber lidar com a heterogeneidade dos alunos que compõe a sala de aula, e tenta, desde então, homogeneizá-los por meio de um modelo didático que os tornam em componentes passivos no processo de ensinoaprendizagem.

Assim, nas aulas de literatura, as características dos movimentos literários, ou escolas literárias, e informações pontuais sobre a obra literária antecedem a sua leitura. A verdade é que, de forma geral, parece não haver espaço para a leitura do texto literário em si, não só o poético, nem mesmo os fragmentos dos textos. Dessa forma, de acordo com as OCNEM (BRASIL, 2006), o programa escolar, o qual deve ser seguido rigidamente pelo professor, parece ter prazo - o fim do ano letivo - e pressa para ser concluído. E, embora seja resguardada alguma autonomia ao docente, este se encontra "encurralado" diante das cobranças da escola por resultados, mesmo que isso signifique a aprovação de alunos que não desenvolveram determinados conhecimentos, os quais estavam previstos para aquele ano.

\begin{abstract}
Como se vê, o texto, que deveria ser o centro das atividades de uma aula de literatura, espaço aberto para a negociação de diferentes leituras e construções de sentido, geralmente acaba por assumir um papel periférico nessa sequencia. Por extensão, na prática, o ensino de literatura no ensino médio não tem alcançado os objetivos propostos pelos programas escolares - entre outros, o desenvolvimento de habilidades leitoras dos alunos - e tem-se limitado a promover a apropriação de um discurso didático sobre a literatura, produzido e representado, em primeira instância, pelo professor e, em segunda instância, produzido socialmente por diferentes agentes: pelo livro didático, pelos programas universitários, pelas referências historiográficas disponíveis para consulta de professores, pelo programa vestibular de algumas universidades, por alguns sites da Internet, etc. (CEREJA, 2004. p. 76)
\end{abstract}

Portanto, espera-se que os novos professores assumam uma postura diferente da que tem sido seguida até o momento por parte da maioria dos professores mais antigos. Principalmente, segundo Cereja (2004), os que tiveram suas formações na década de 70, ano no qual a linguística estruturalista começava a se desenvolver, influenciando os estudos literários da época. A teoria estruturalista postulava, basicamente, que o significado do texto 
literário seria imanente ao próprio texto, deixando de lado na hora da análise, e no processo de significação da obra, qualquer coisa, e isso inclui os leitores/alunos, que não esteja dentro do próprio texto.

O perfil deste novo professor é de um leitor assíduo, o qual não usa o LDP para suprir as suas lacunas de leitura literária e/ou como justificativa pela falta de tempo de preparar aula. Agazzi (2014, p. 456) reflete:

Se é preciso que o professor pense e repense suas práticas a partir da reflexão crítica sobre sua concepção de ensino da literatura, é necessário que ele mesmo experimente plenamente os textos literários ao longo da sua formação inicial - e continuada -, a fim de que se cumpra uma educação literária na dinâmica do cotidiano e na história.

Sendo assim, o professor/mediador capaz de sugerir, a depender da necessidade do público leitor, títulos de obras que não figurem no livro didático de Português, textos que possam desenvolver a prática de leitura para além dos muros da escola, desenvolvendo verdadeiramente as habilidades de leitura, análise e produção de texto.

Contundo, é importante indagar, diante das influências, que as provas de vestibulares ou concursos têm sob a prática docente, além da cobrança da escola para se cumprir com o cronograma letivo, que autonomia resta ao professor?

Portanto, é importante, apesar das dificuldades, criar mecanismos para que se possam desenvolver as metas de aprendizagem programada para cada ano letivo sem que tenha de recorrer, no caso do ensino de literatura, à inadequada metodologia de ensino (do séc. XX em diante). Esta que recorta da história da literatura aquilo que há de mais interessante, de acordo com a crítica canônica, transformando os recortes em informações descartáveis, e que deverão ser decorados pelos leitores. Fazendo parecer, pois, que o único objetivo da escola para com os alunos é fazer com que estes consigam ingressar em uma universidade ou um curso técnico.

No exercício da docência quase todos os meios são fontes de transmissão de conhecimentos ou a própria fonte para o conhecimento, como podemos perceber a partir de uma série espanhola, lançada no ano de 2016 na Netflix, na qual um professor de filosofia chamado Merlí - desafia o sistema tradicional da escola com sua metodologia nada ortodoxa, buscando, por meio de alguns questionamentos e uma perspectiva diferente de abordar o conteúdo filosófico, desenvolver nos alunos o real sentido de se estudar a Filosofia. Nessa série, podemos perceber o esforço do professor para trazer sentido para suas aulas e ao mesmo tempo não repetir a metodologia de ensino, compartilhada pelos outros professores, que tende 
a homogeneizar o processo de ensino e excluir, por meio de comentários como "aquele é problemático" ou "ele não tem futuro", os alunos que não se encaixam nesse modelo de ensino arcaico e excludente.

\section{CÍRCULO DE LEITURA: RESULTADOS E ANÁLISES}

\subsection{A escolha da crônica e da autora}

Em uma entrevista de um programa chamado Poesia e prosa, com Maria Bethânia falando sobre Clarice Lispector, publicada em 04 de julho de 2016, a apresentadora citou uma frase - sobre a escritora homenageada - do convidado especial Caetano Veloso, que dizia: "Lê Clarice é como conhecer uma pessoa".

Debruça-se sobre a obra de Clarice Lispector é adentrar um território reversível, onde tudo é passível de se transformar no seu oposto; onde criação e destruição se alternam no ritual do eterno retorno do mesmo. Onde a matriz primordial da linguagem se desdobra em verbo, gestando esboço de seres e formas. É confrontarse com identidades precárias, que se agitam em constelações especulares, como as figuras de um caleidoscópio que se compõe, se decompõe e se recompõe (KAHN, 2000. p. 09).

Portanto, foi diante dessa possibilidade que o texto clariceano propõe ao seu leitor de experienciar a construção do outro e de si mesmo, que a crônica "Mineirinho", do livro Para não esquecer (1999), foi escolhida para ser trabalhada com os jovens leitores dessa pesquisa. Assim, na escolha por esse texto específico objetivou-se fazer com que os leitores pudessem experienciar o lugar do outro na sociedade e como esse pode lhe afetar.

Outro motivo, este mais pessoal, para a escolha por Clarice Lispector em detrimento de algum outro autor foi porque, sendo leitor devoto de suas obras, seria mais confortável trabalhar algum texto dela. No entanto, não poderia ser qualquer texto, teria de ser um que fosse atual - ou atemporal - e que provocasse no leitor reflexões sobre a sua própria realidade.

Conforme afirma Rosebaum (2010) em relação ao texto "Mineirinho":

Desde a primeira linha, então, o eu narrador e nós - todos, incluindo os leitores estamos imersos no mesmo dilema, na mesma procura. [...] A interioridade se vê atiçada, acuada, pela morte de Mineirinho. A presença perturbadora do outro é a mola propulsora do gesto narrativo clariciano, que não se rende ao fato consumado, desprende-se desse, interioriza a realidade e faz da linguagem espaço de uma consciência indagativa (p. 172). 
Dito isso, vimos na escolha dessa crônica um caminho de propor uma leitura cativante - a um grupo de jovens do último ano do ensino médio que pudesse ser melhor aceita, provocando discussões e reflexões.

\section{2. "Mineirinho"}

No dia 01 de Maio de 1962 é assassinado com treze tiros no Rio de Janeiro pela polícia carioca um morador de favela chamado José Rosa de Miranda, porém, mais conhecido pela alcunha de Mineirinho. Considerado entre os moradores da favela como um Robin Hood, Mineirinho era procurado, vivo ou morto, pela polícia carioca devido aos seus vários crimes. No entanto, a forma de sua morte causou repercussão nos jornais da época e principalmente entre a população do morro em que morava, ganhando um filme, em 1967, dirigido por Aurélio Teixeira, que trazia como título "Mineirinho: vivo ou morto", e, um mês depois do assassinato, a história do Robin Hood carioca vira crônica na "voz" da escritora Clarice Lispector.

A crônica provoca no leitor sentimentos contraditórios, mas, principalmente, de injustiça, como nas primeiras linhas já é possível notar a complexibilidade de sensações experienciadas pelas personagens "É, suponho que é em mim, como um dos representantes do nós, que devo procurar por que está doendo a morte de um facínora. E por que é que mais me adianta contar os treze tiros que mataram Mineirinho do que os seus crimes. Perguntei a minha cozinheira o que pensava sobre o assunto. Vi no seu rosto a pequena convulsão de um conflito, o mal-estar de não entender o que se sente, o de precisar trair sensações contraditórias por não saber como harmonizá-las. Fatos irredutíveis, mas revolta irredutível também, a violenta compaixão da revolta. Sentir-se dividido na própria perple-xidade diante de não poder esquecer que Mineirinho era perigoso e já matara demais; e, no entanto, nós o queríamos vivo.",

Ao longo do texto o leitor vai se deparando com o seu lugar na sociedade e como o outro faz parte de cada um de nós enquanto um grupo. Dessa forma, várias leituras podem ser feitas da crônica "Mineirinho", tais como, psicológica, social, política, histórica, etc. A leitura desse texto, em outras palavras, é e propõe um olhar atento sobre mim e sobre o outro.

O pobre leitor se vê [...] destituído de um suporte de leis rígidas para estabelecer limites claros entre o eu e o outro, o certo e o errado, a verdade e a falsidade. Nenhum valor, pode-se dizer, metafísico sustenta-se a essas alturas do texto fora da sua inserção histórica e contextual. [...] Diante disso, a visão de um homem

\footnotetext{
${ }^{3}$ Para a leitura da crônica completa, ver anexo.
} 
metralhado se torna porta de acesso tanto para um questionamento da justiça convencional (mata-se um bandido porque assim deve ser), quanto para a miragem de uma justiça outra "justiça prévia" nas palavras do texto, "aquela que vê o homem antes de ele ser um doente do crime" (ROSENBAUM, 2010. p. 10).

Assim, a escolha por essa crônica específica buscou provocar nos jovens leitores discussões tanto sobre o texto, mas, principalmente, sobre a realidade na qual estão vivendo. Um olhar mais local, aonde uma vez por mês é anunciado pelas ruas da cidade, em um carro de serviço comunitário, o falecimento de uma pessoa. Por exemplo, há um ano, em 2017, um ex-professor da escola-campo de pesquisa foi assassinado, e não se sabe até então o motivo.

Diante disso, fundamentamos, então, a escolha da crônica "Mineirinho", pois, segundo Silva (2005. p. 97) “enquanto representação mimética da realidade, os textos literários podem dialogar com o contexto histórico-social do aluno, servindo como fonte de denúncia das mazelas sociais". Portanto, a escolha desse texto tentou aproximar a literatura da realidade uma vez que o ensino literário na escola parece falar de um outro mundo e um outro tempo que não os deles (leitores) - e permitindo que a obra e o leitor pudessem conversar entre si, e a partir desse diálogo pudéssemos ouvir a voz autônoma desses jovens com reflexões e posicionamentos próprios.

\subsection{A escola-campo de pesquisa e o grupo de leitores}

A escolha da escola Albertina da Costa Soares, localizada no distrito de Camela, na cidade do Ipojuca, foi motivada, primeiro, por eu ter um bom relacionamento com a direção e professores, pois já havia trabalhado lá nos anos de 2016 e 2017, enquanto professor de Inglês pelo Programa Ganhe o Mundo (PGM), um projeto do Governo do Estado de Pernambuco que oferece curso de Inglês para alunos do primeiro ano do ensino médio de escola pública.

Segundo, foi nessa escola na qual desenvolvi meus dois Estágios - supervisionado e de regência -, o que me permitiu ter mais contato com os alunos, dessa vez enquanto professor de Português em formação. O grupo escolhido para fazer parte da leitura do texto Mineirinho contou com 25 alunos - todos residentes do mesmo distrito -, dos quais 15 já haviam sido meus alunos, ou de Português ou de Inglês.

O grupo em questão, no geral, segundo os professores, é o melhor dentre os terceiros anos para se trabalhar, devido ao interesse que os alunos demostram em aprender. Nesse sentido, a escolha da turma $\left(3^{\mathrm{a}} \mathrm{B}\right)$, do turno da manhã - a escola é de regime semi-integral se deu a pedido e indicação do professor de Português da escola-campo de pesquisa. São jovens, em sua maioria, que buscam ingressar no ensino superior. Todos fizeram o Enem 
desse ano (2018), embora alguns dos jovens não soubessem ainda se desejam fazer faculdade; citaram cursos técnicos como primeira opção, pois, segundo eles, é mais rápido e fácil de conseguir um emprego.

\subsection{Círculo de Leitura}

Diante das dificuldades aqui já listadas para o desenvolvimento efetivo das práticas de letramento literário em contexto escolar, para o público, mais especificamente, acreditamos ser a prática de Círculos de leitura uma das formas mais efetivas de se ler, discutir e refletir literatura em sala de aula, ou fora dela:

\footnotetext{
Porque os círculos de leitura possuem um caráter formativo, proporcionando uma aprendizagem coletiva e colaborativa ao ampliar o horizonte interpretativo da leitura individual por meio do compartilhamento das leituras e do diálogo em torno da obra selecionada (COSSON, 2014. p. 139).
}

Portanto, optamos por essa prática de leitura - literária ou não - nessa pesquisa como meio de verificar os objetivos desse trabalho. Assumimos, é claro, a possibilidade de não haver entre o grupo escolhido o hábito de se reunirem entre si para ler e discutir literatura, mesmo não sendo sob a influência da escola, tendo o professor como mediador.

Dito isso, fizemos certas adaptações para atender aos objetivos dessa pesquisa e as possíveis limitações do grupo de jovens leitores na estrutura do Círculo de Leitura apresentado por Cosson (2014). De acordo com o mesmo autor, para que se possa haver de fato uma prática - tornando-se em hábito mais tarde - de leitura literária, inicialmente em contexto escolar, é preciso que alguns passos sejam seguidos para oferecer ao aluno e ao texto liberdade para se expressarem dialogicamente e tornar a prática do Círculo efetiva.

Cosson (2014) explicita algumas dessas características essenciais para o desenvolvimento de círculos de leitura referindo-se a um modelo bem sucedido do professor e escritor norte-americano Harvey Daniels (2002). Primeiro, o texto/obra a ser lido(a) e discutido deve ser escolhido pelo leitor, mas antes dessa primeira etapa é preciso que haja, de preferência, um pequeno acervo físico (biblioteca, já que estamos nos refendo à escola, ou a coleção particular do próprio professor, já que a compra de livros pode não ser realizada pela maioria dos jovens) disponível para estes leitores. Acrescentaríamos, na organização desse acervo, obras dos próprios alunos que desejassem compartilhar seus livros entre os colegas. 
Assim, o professor poderia igualmente incluir entre os textos disponíveis para os jovens leitores títulos do cânone literário.

Segundo, os grupos formados para lerem determinado título devem ser pequenos, de quarto a seis pessoas, no máximo, e a cada nova obra, um novo grupo deverá ser formado. Permitindo assim que os leitores tenham contato com outros colegas e acesso a outras reflexões e experienciais de vida diferentes.

Terceiro, cada grupo deve ler uma obra diferente, e as atividades de leitura ou os encontros para o compartilhamento das reflexões desenvolvidas devem seguir um cronograma (sugerido pelos próprios leitores ou pelo mediador) para que outros textos possam ser lidos e discutidos.

Quarto, cabe aos leitores desenvolverem formas de apresentar suas reflexões de cada leitura feita, podendo ser de "uma simples exposição oral" a uma encenação. São igualmente livres, também, nas escolhas dos tópicos a serem desenvolvidos/discutidos em relação ao texto, embora, acreditamos, não impede de o mediador levantar questionamentos para que, se necessário, a compreensão da obra seja aprofundada.

Quinto, ao que se refere à avaliação, julgamos "não ser necessária", não em termos de notas, como o sistema escolar pede dos professores, pois o objetivo dos círculos de leitura é desenvolver o hábito da leitura e, entre outras coisas fundamentais, formar leitores autônomos. Dessa forma, o professor pode observar nas produções dos leitores supostas dificuldades em relação à leitura, argumentação, capacidade de síntese, fazer referenciação entre o texto lido e outras obras já trabalhadas ou à sua própria realidade, e etc. e a partir dessa observação desenvolver métodos que ajude o leitor a superar as dificuldades enfrentadas.

São essas, resumidamente, algumas das características que compõe o modelo de Círculo de leitura do professor Harvey Daniels (2002) mencionado por Cosson (2014). E, embora, pareça que em nossa prática de pesquisa tenhamos "ignorado" algumas dessas características, voltamos a dizer que deste modo o fizemos frente ao nosso objetivo: analisar os efeitos da prática docente - que se respalda na transmissão e repetição de informações específicas e decoráveis sobre a obra literária, o autor e o contexto sociopolítico de publicação do texto -, observada na disciplina de Estágio supervisionado II, sobre os alunos enquanto leitores em formação.

\subsection{Leitura da crônica}


A leitura do texto foi realizada no dia 25 de Outubro de 2018, no turno da manhã, logo após os alunos voltarem do intervalo às $10 \mathrm{~h} 30 \mathrm{~min}$, contribuindo para o atraso da realização da leitura. Depois da chegada de todos, expliquei que eu estava ali desenvolvendo uma pesquisa de leitura para o meu trabalho de conclusão de curso de Língua Portuguesa pela Universidade Federal de Pernambuco.

Informei que o objetivo da pesquisa era avaliar como tem sido o ensino de literatura na escola, na qual estavam inseridos, por meio das leituras reflexivas que cada um fizesse sobre o texto que iriamos ler e discutir. Deste modo, pedi que ficassem à vontade para discutirem e expor como a leitura havia sido recebida por eles, se provocou alguma reflexão ou questionamento, se seria possível relacionar o texto a sua realidade, de qual forma, etc. Além disso, solicitei que buscassem se referir a elementos diversos da obra em suas reflexões, argumentando seus pontos de vista; os outros grupos poderiam contribuir com suas reflexões também se desejassem.

Depois, reafirmei dizendo que o objetivo daquela leitura era discutir as ideias presentes no texto e ouvirmos as reflexões individual e compartilhada de cada aluno, portanto, se alguém não quisesse ou não se sentisse disposto a participar, poderiam sair da sala. Neste momento, alguns alunos mostraram-se hesitantes, mas quando o primeiro levantou, outros setes levantaram e saíram da sala.

Primeiramente foi feito um grande círculo, como podemos ver na imagem ${ }^{4}$ a seguir:

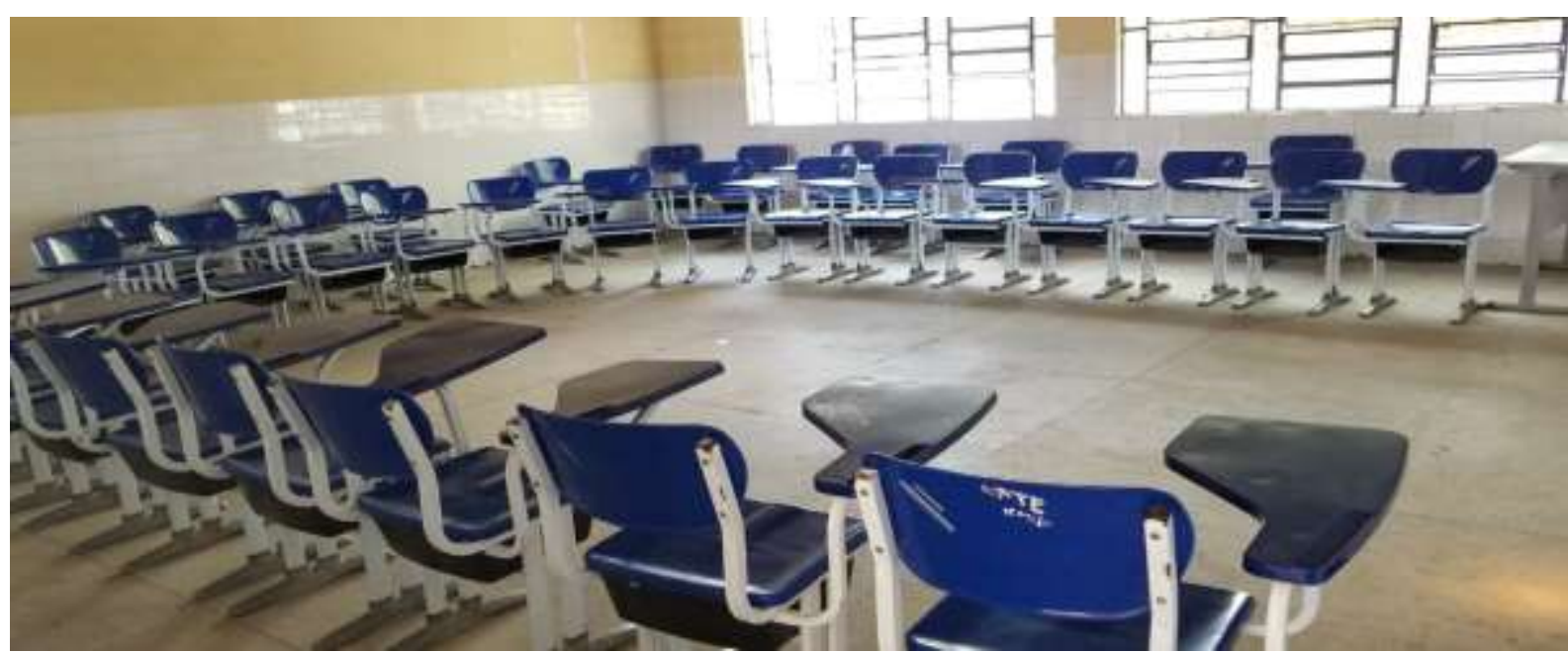

Depois que todos os jovens estavam sentados, iriamos então começar a leitura da crônica, quando a professora de Educação Física pediu para falar com os alunos sobre uma brincadeira feita com um dos colegas de sala envolvendo "furto" - supostamente teriam

\footnotetext{
${ }^{4}$ Imagens ilustrativas, pois os jovens, em sua maioria, não queriam fazer nenhum tipo de registro visual.
} 
colocado algum pertence de um dos jovens daquele grupo na bolsa de um outro. Quando enfim a professora saiu da sala houve ainda uma pequena prolongação do assunto. Enquanto isso, distribui cópias do texto para cada leitor, e pudemos começar a leitura.

De frente para os jovens pus-me interpretar o texto em voz alta enquanto eles acompanhavam fazendo uma leitura em um tom mais baixo. Houve três pausas para explicar os significados das palavras facínora, baluartes, e honorabilidade, pois julguei ser necessário. Quando terminamos, pedi que formassem cinco grupos para reler o texto e discutirem entre si, depois voltaríamos a formação inicial de um único grande círculo para expor e discutir as reflexões feitas por cada leitor. Imagem a seguir:

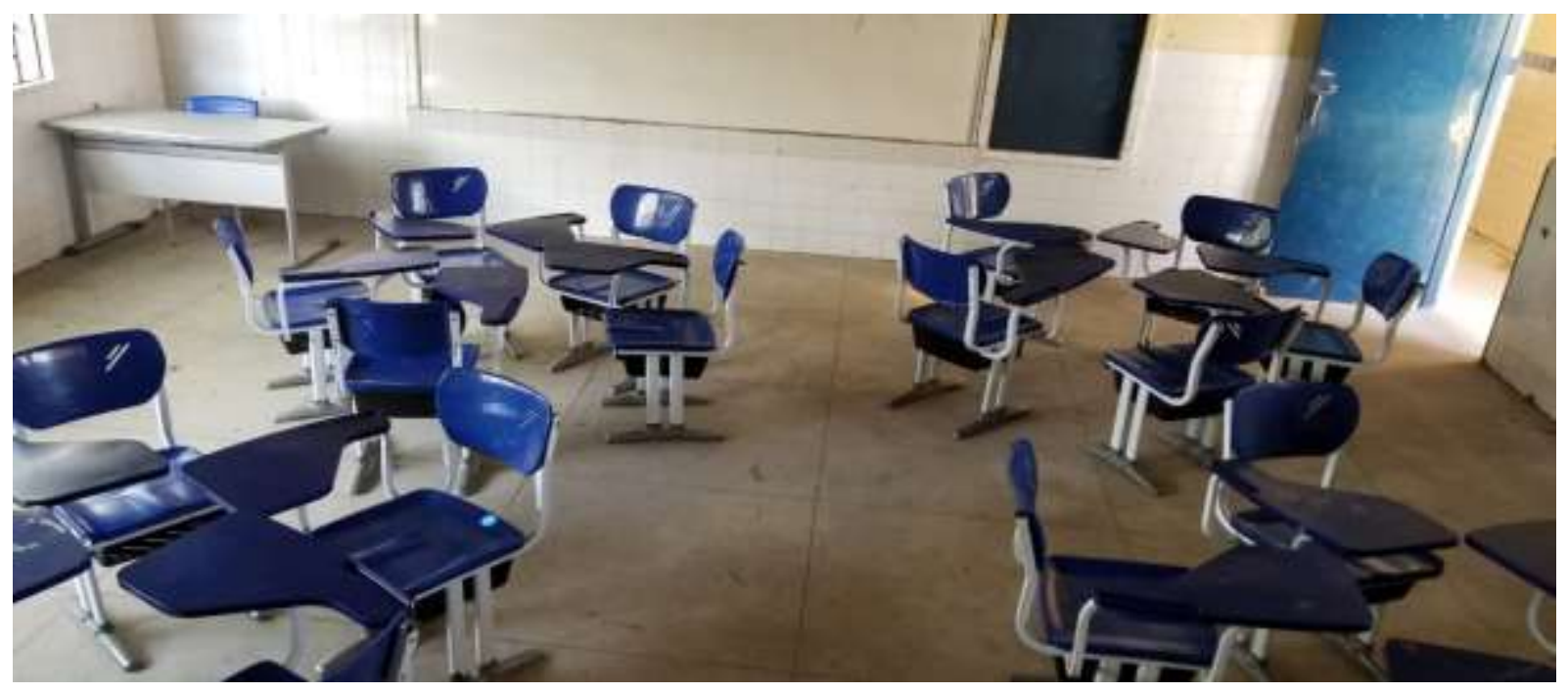

Enquanto os jovens discutiam o texto, caminhei por entre os grupos observando as discussões, todas muito parecidas, destacando, de modo geral, aspectos da superfície do texto, sem que fosse feita uma leitura e discussão reflexivas aprofundadas. O que nos remete, segundo Silva (2005, p. 92), para a falta de familiaridade dos leitores com o gênero conto na escola, pois a escola parece valorizar a leitura dos romances. No entanto "Os alunos nem sempre se sentem motivados a ler romances, pois os resumos das obras já constam nos livros didáticos ou são fornecidos pelos professores de literatura como 'receitas prontas' para orientar a 'pseudoleitura' que os estudantes deverão fazer".

Percebi que em cada grupo ao menos uma pessoa não estava interessada em compartilhar reflexões, ou usavam o celular ou conversavam entre si sobre outros assuntos em um tom mais baixo para não chamarem a atenção. Mostrando-nos, dessa forma, uma realidade comum ao dia a dia de uma escola pública - alunos sem motivação para ler, pois presumem, de acordo com o seu histórico escolar, que a leitura proposta pelo professor é algo chato. 
Em um dos grupos, uma leitora chamava a atenção dos colegas para uma das passagens do texto na qual a autora utilizava a palavra casa: "E continuo a morar na casa fraca. Essa casa, cuja porta protetora eu tranco tão bem, essa casa não resistirá à primeira ventania que fará voar pelos ares uma porta trancada. Mas ela está de pé, e Mineirinho viveu por mim a raiva, enquanto eu tive calma.", dizendo que talvez isso fosse uma metáfora (embora não soubesse explicar o porquê achava isso), e o seu grupo pareceu não ouvi-la ou não entendê-la e ignorou seu comentário.

Talvez possamos aproximar a leitura e a posição dessa leitora em seu grupo frente às análises, desenvolvidas por Silva (2005), das leituras e intepretações do texto literário realizadas por alunos do primeiro, segundo e terceiro ano do Ensino Médio. A autora percebeu que duas das leituras interpretativas feitas de um conto de Gilvan Lemos haviam seguido perspectiva de interpretação diferente das dos demais, afirmando que os dois alunos e questão teriam ido além da superfície do texto, percebendo as entrelinhas deixadas pelo conto.

Essas duas leituras singulares, segundo a mesma autora (2005. p. 123), pode ser recebida/percebida como interpretações erradas pelo professor, "Será que os alunos que realizaram uma leitura diferente teriam suas respostas valorizadas no espaço de sala de aula? Será que as respostas dadas por esses alunos não seriam sufocadas pela leitura já instituída pelo professor e pelo sistema escolar?”. Acreditamos ter sido o caso da jovem leitora Gabriela entre seus colegas de grupo ao compartilhar sua interpretação de um trecho da crônica.

Pedi a essa leitora que organizasse melhor as ideias para depois explicar para os demais sobre essa questão do uso da metáfora, pois era algo interessante. Mas na hora que estavam compartilhando as reflexões - como veremos mais adiante - ela não comentou a respeito da metáfora usada pela autora ao se referir a uma casa. Perguntei se tinha esquecido, e disse-me que não, só preferiu não falar porque não sabia explicar. Dessa forma sugeri que os outros leitores pensassem sobre esse ponto levantado pela colega de turma, e se alguém chegasse a uma resposta, poderia compartilhar com os demais - no entanto, ao fim do compartilhamento das leituras ninguém quis responder.

Ao fim da etapa dos pequenos grupos voltamos à formação de um único círculo para compartilhar as reflexões feitas. Perguntei quem gostaria de começar, um leitor levantou a mão (chamarei de João, ficticiamente, como os demais a serem mencionados) e começou a falar. Ao fim, como ninguém havia interferido, perguntei se alguém gostaria de acrescentar algo, mas ficaram em silêncio. Em seguida, questionei se alguém do grupo de João dividia do mesmo ponto de vista ou se tinha uma leitura diferente da dele, uma leitora (Paula) do grupo 
de João disse que eles haviam conversado entre si e chegado a uma mesma conclusão, assim, decidiram eleger um representante de fala para a equipe.

Talvez a ideia de Paula tenha influenciado os demais leitores ou talvez eles tivessem tido a mesma ideia naturalmente, pois, apenas quatro pessoas falaram de suas leituras feitas, assumindo, como um porta-voz, o papel de representante do grupo.

\subsection{As leituras compartilhadas e o silêncio enquanto réplica.}

Na tentativa de compreender melhor o que estava presente nas - e por trás das leituras feitas pelos jovens leitores da crônica "Mineirinho", destacamos seis características presentes em suas reflexões sobre o texto lido para a nossa análise, são elas: a escolarização da atividade (o círculo de leitura), diversidade de leituras sobre um único referencial, interpretação do texto mais pontual: sem extrapolação, e o silêncio.

Chamamos aqui por "a escolarização da atividade" o modo de leitura do texto literário por uma turma de leitores do último ano do Ensino Médio. Desta maneira, percebemos e caracterizamos a forma desses jovens trabalhar (em grupo) e expor suas reflexões ao optaram, sem consultar o mediador, por eleger um representante de "fala" responsável por compartilhar as ideias desenvolvidas ao longo da leitura dentro do pequeno grupo, que tinha como objetivo intensificar o contato entre os leitores e organizar melhor as suas reflexões.

Embora tenhamos informado de que cada leitor deveria compartilhar sua leitura interpretativa/reflexiva com a turma. Por outro lado, como o nosso objetivo era analisar de que forma eles iriam receber, trabalhar e refletir o texto proposto, "permitimos" que apenas um leitor por grupo fizesse suas considerações sobre a crônica. No entanto, os demais membros de todas as equipes foram questionados se tinham alguma contribuição para fazer aos comentários dos seus representantes, assim como para os dos outros grupos, porém não houve contribuição alguma.

Enquanto pequenos grupos, percebemos, como todo trabalho/atividade passado pelo professor em sala de aula, para o qual os jovens teriam de se reunirem com outros, que enquanto dois ou três leitores se movimentavam procurando ler e discutir o texto, um e outro fingia que lia ou ficava conversando com o colega sobre assuntos que não diziam respeito a atividade. Ao "fim" da atividade uma única pessoa fica responsável por apresentar o trabalho, é claro, quando o professor não exige que todos falassem um pouco. É neste momento que podemos ver aos alunos em frente à turma com um pedaço de papel na mão lendo as 
informações copiadas minutos antes de sua apresentação, já que estes não se engajaram na produção da atividade. A seguir, vejamos os nomes dos representantes de cada grupo:

\begin{tabular}{|l|l|l|l|l|l|}
\hline & Grupo A & Grupo B & Grupo C & Grupo D & Grupo E \\
\hline Representantes & Júlia & Gabriela & Larissa & João & Carlos \\
\hline
\end{tabular}

Quadro 1: Nomes dos representantes dos grupos ${ }^{5}$

A segunda característica por nós percebida nas reflexões de quatro dos cinco jovens leitores é a que designamos por "diversidade de leitura de um único referencial”. Assim nos referimos ao modo de interpretar o texto pelos alunos ao notar que a violência da morte de Mineirinho ganhou uma interpretação e um foco diferente para cada leitor.

Por exemplo, a leitora Júlia interpretou a morte de Mineirinho do ponto de vista da autora, que se responsabiliza, de certa forma, pela crueldade na forma pela qual o bandido foi morto, como podemos perceber nesse trecho da crônica:

\footnotetext{
Até que treze tiros nos acordam, e com horror digo tarde demais — vinte e oito anos depois que Mineirinho nasceu - que ao homem acuado, que a esse não nos matem. Porque sei que ele é o meu erro. E de uma vida inteira, por Deus, o que se salva às vezes é apenas o erro, e eu sei que não nos salvaremos enquanto nosso erro não nos for precioso. Meu erro é o meu espelho, onde vejo o que em silêncio eu fiz de um homem. Meu erro é o modo como vi a vida se abrir na sua carne e me espantei, e vi a matéria de vida, placenta e sangue, a lama viva (LISPECTOR, 1999. p. 124-125).
}

A jovem leitora percebe essa posição da autora como parte de um grupo social com direitos e deveres, relaciona e adapta (ou poderíamos dizer: ressignifica) a leitura da crônica ao seu dia a dia ao se colocar no lugar da autora, que percebe seu papel e importância na sociedade, como podemos notar na reflexão da Júlia.

\footnotetext{
para mim isso foi ... é bem simples:: é o dia a dia da gente ... é ver uma pessoa ali doente ... e não querer ver, fechar os olhos, porque se eu não estou vendo, eu não vou ter a necessidade de ajudar eu não vou me sentir mal em querer ajudar aquela pessoa... é isso... fechar os olhos para a realidade (Júlia, 25/10/2018)
}

A leitura feita pela Gabriela parece responder - ao usar a preposição adversativa mas - à reflexão feita pela Júlia sob um outro ponto de vista ao afirma que "é o nosso dia a dia .... mas envolvendo a criminalidade". Enquanto a Júlia percebia e compreendia a autora como

\footnotetext{
${ }^{5}$ Nomes fictícios, porém, as escolhas dos nomes foram relacionadas ao gênero de cada leitor, no caso, foram três meninas e dois meninos
} 
uma representante de uma sociedade responsável pelo assassinato brutal de Mineirinho, Gabriela assume dois pontos de interpretação.

O primeiro refere-se à posição da autora ao se designar por "sonsa", interpretando esse adjetivo a partir de uma posição de medo frente à criminalidade, de forma geral, presente na sociedade, como podemos observar nesse trecho da reflexão da leitora: "tipo ... se a gente não fechar os olhos ... se a gente ver e não ficar calado numa criminalidade ... ou alguma coisa ... a gente pode pagar também".

O segundo compreende Mineiro antes mesmo de ser um bandido, assassino facínora, porque ele é antes de tudo, uma pessoa "porque dentro dele poderia existir uma coisa boa... e::: ... quando ele morreu levou as coisas ruins que ele cometeu ... mas também uma coisa boa que poderia ter existido dentro dele".

A leitura feita pela jovem leitora Gabriela nos apresenta um outro Mineirinho, oposto ao da escritora Clarice Lispector. Aquele é delimitado, em termos de profundida reflexiva, por uma dicotomia entre Bem e Mal. Enquanto este vai além do "bom" e do "mal", porque ele a representação de uma sociedade, uma crítica à violência da Justiça, o "eu" que rejeitamos, mas que nos acerta tal como uma vertigem diante da barbaridade de sua morte.

Além disso, a leitora mostra dificuldade em apresentar suas reflexões, como veremos na leitura de seu comentário a seguir - grifamos a passagem referida acima para melhor visualização.

é o nosso dia a dia .... mas envolvendo a criminalidade ... tipo assim:: ... "por que está doendo a morte de um facínora ... de um criminoso?” por que as pessoas choram ... por a morte dele já que ele cometeu tantos crimes? aí a cozinheira fala que ... porque dentro dele poderia existir uma coisa boa... e:.: ... quando ele morreu levou as coisas ruins que ele cometeu ... mas também uma coisa boa que poderia ter existido dentro dele ... e que a pessoa:: que matou ele ... não foi um herói ... mas se tornou um criminoso também ... porque está cometendo um crime ... “e descumprindo uma lei que é a de que não matarás” ... que essa:: lei ... fez... foi criada ... neh? ... pras pessoas ... terem medo de matar:: ... e também se protegerem ... porque ... se eu não mato:: ... as pessoas não vão me matar por causa da lei ... porque ela pode ter medo ... e:: também essa parte ... “eu não enxergo a minha revolta ... e o meu amor ... guardados ... se:: eu não for sonsa ... minha casa estremece" ... tipo ... se a gente não fechar os olhos ... se a gente ver e não ficar calado numa criminalidade ... ou alguma coisa ... a gente pode pagar também ... a gente tem que fechar os olhos pra muita coisa que a gente vê ... muita:: coisa errada ... a gente tem que fechar os olhos ... fingir de sonso ... fingir que não sabe ... que não viu... éh:: ... "eu devo ter esquecido ... que embaixo da casa há um terreno" 
... embaixo da casa ... pra mim ... a casa é a estrutura da gente ... que a casa é frágil ... mas o terreno é a estrutura ... a casa pode ser derrubada mas o terreno não ... então ... por isso no final ele fala que não quer a casa ... ele quer uma justiça ... uma estrutura ... e não uma coisa frágil (Gabriela, 25/10/2018).

A reflexão da jovem Larissa parece conceber a cozinheira - diante da morte de Mineirinho - como foco de sua argumentação, embora se mostre confusa ao confundir a voz da narradora personagem com a voz da empregada. Então dividiremos em duas partes nossa análise sobre o comentário da leitora.

O primeiro teria como foco a empregada, que se mostrou revoltada diante da morte de Mineirinho. De acordo com a leitura da jovem sobre a crônica, a cozinheira tinha algum laço com o morto. Em seguida ela completa a reflexão, agora trocando sem perceber, as personagens, usando diálogos da narradora-personagem, assim, compreendeu este laço entre a cozinheira e Mineirinho como uma representação de um filho, como se pode notar nessa passagem: "o filho dela poderia ser um bandido, também".

Ao fim de sua reflexão, Larissa se aproxima da leitura feita pela Gabriela que compreendeu a revolta das personagens porque viam Mineirinho não apenas como um bandido, mas como um homem igual a todos nós, como se pode notar na parte destacada de sua análise. Desse modo, conforme Sila (2005. p. 117), "Essas respostas revelam a capacidade representativa da literatura, ou seja, sua função mimética como um aspecto importante na recepção dos leitores, os quais a partir de repertórios diversos, percebem a função social da literatura".

o que a gente entendeu:: ... foi o seguinte ... que essa mulher:: a:: cozinheira ... ela se:: sentiu:: revoltada pela morte do:: mineirinho porque ... de certa forma ela tinha alguma ligação com ele porque ... ela falou em um:: trecho que:: - - eita ... o do espelho ... onde é que tá - - "meu erro é o meu espelho onde vejo o que em silêncio eu fiz de um homem", ou seja .... ela tem uma certa... o filho dela poderia ser um bandido também ... tá ligado? ... ela disse que doeu mais ou trezes tiros que ele levou do que os crimes dele ... sabe? porque:: ela pensou ... se as pessoas não tivessem ... matado o:: mineirinho ... ele poderia ... se arrepender ... e:: virar uma pessoa boa ... neh? mas mataram ele ... e ela ficou revoltada por causa disso (Larissa, $25 / 10 / 2018)$

A leitura de João sobre a crônica se aproxima da que foi feita pela leitora Júlia, percebendo a posição assumida pela narradora-personagem, como se pode notar nesse trecho “É, suponho que é em mim, como um dos representantes do nós, que devo procurar por que 
está doendo a morte de um facínora." (LISPETOR, 1999.p. 123). Podemos notar a proximidade da compreensão do texto pelo Joao as de Gabriela e Larissa que percebem que o lugar ocupado por Mineirinho na sociedade pode ser comum para qualquer pessoa, como afirmou ao fim da sua breve leitura.

na minha concepção ... neh? o que a mulher tentou passar aqui nesse texto ... foi ela se colocando no lugar do garoto ... que independente:: querendo ou não ninguém quer:: tá no lugar dele ... e eu acho que ela deixou bem claro ... nesse texto que isso pode acontecer com qualquer outra pessoa (João, 25/10/2018)

Nosso próximo ponto a ser discutido e analisado refere-se aos limites interpretativos do texto literário, sabemos que quando o assunto é literatura pode haver diversas leituras interpretativas de uma única obra por várias pessoas ou pela mesma pessoa ao longo do tempo. No entanto, todo texto literário, apesar das entrelinhas - espaços para suposições diversas - estabelece um limite no campo da interpretação (LANGLADE, 2013. p. 33), mesmo que pareça não existir.

Por exemplo, tomando a crônica Mineirinho como exemplificação, podemos afirmar que há apenas duas mulheres dialogando, e podemos imagina que ambas ou uma delas são/é transgênero(s), no entanto não podemos afirmar. Dessa forma, a reflexão sobre o texto do jovem leitor Carlos pareceu levar em conta não o que a crônica tinha a dizer, e sim uma leitura de mundo própria. Essa leitura é anterior ao contato com o texto "sobre Mineirinho", ela está baseada na experiência diária do leitor, como é possível perceber em seu comentário.

entendi que ... éh::: ... o fato dessa cozinheira ter:: tido de certa forma ... sentido muito a morte do mineirinho foi... pelo que entendi ele não teve uma infância fácil ... ele tinha muitos sonhos ... para si mesmo e:: como parecia muito difícil de se realizar ... através do crime ele viu um jeito mais fácil ... ele só queria realizar os seus sonhos (Carlos, 25/10/2018)

Por outro lado, percebemos o esforço imaginativo do leitor ao (re)criar uma imagem do Mineirinho, que talvez não seja possível identificá-la com as informações presentes no texto. Por conseguinte, deveríamos considerar esta leitura da crônica uma extrapolação/generalização interpretativa, pois, conforme Langlade (2013. p. 33), apesar da liberdade dada ao leitor diante das entrelinhas e os espaços deixados pelo texto para serem preenchidos com experiências pessoais da realidade de cada um, é ainda assim, "uma liberdade vigiada", ou negaríamos o caráter fictício da obra literária ao sobrepor o real sobre a ficção confundindo os dois? 
Diante disso, percebemos a importância da prática do Círculo de leitura, o qual tende a propiciar aos leitores, como Carlos, por exemplo, o contato com outros pontos de vistas, outras reflexões, sendo possível fazê-lo questionar-se se suas reflexões estão realmente de acordo com os limites interpretativo do texto.

Nosso último ponto para análise e discussão observado nas leituras da crônica feitas por leitores do último ano do ensino médio é o "silêncio" do grupo diante do compartilhamento das flexões desenvolvidas pelos participantes do Círculo. Com exceção da leitora Gabriela, que argumentou em posição oposta à leitura feita pela colega Júlia, embora não o tenha feito de forma direta citando a outra participante, por exemplo.

Observamos nesse silêncio o reflexo de um ensino, principalmente, do conteúdo literário, que assume o leitor na sala de aula como um ser passivo,

[...] Quando muito, o aluno participa mais ativamente somente na parte final desse processo, momento em que é solicitado a responder a algumas perguntas de um questionário proposto pelo professor ou pelo manual didático acerca da leitura de um texto. E, mesmo assim, raramente essas questões exigem dele um esforço interpretativo maior [...] Geralmente, elas limitam-se a solicitar o reconhecimento do assunto principal do texto, de um outro recurso de expressão (metáfora, aliteração, etc.) e a identificação no texto das principais "características" do estilo de época enfocado (CEREJA, 2004. p. 75-76)

Nesse sentido, é o professor o centro/detentor do conhecimento e os leitores, compreendido pela escola como um grupo homogêneo, têm a função de acumular a maior quantidade de informação possível transmitida por ele.

\section{CONSIDERAÇÕES FINAIS}

A pesquisa aqui desenvolvida buscou verificar, analisar e discutir a recepção do texto literário por alunos, leitores em formação, do último ano do Ensino Médio de uma escola pública na cidade de Ipojuca-PE. Dessa forma, nosso objetivo não era realizar, com a turma escolhida para o estudo de campo, uma nova abordagem da obra literária de modo geral, se opondo, assim, a uma metodologia do ensino da Literatura baseado na repetição/memorização de informações, e sim perceber e refletir sobre o desenvolvimento de habilidades (básicas) de leituras e interpretação do texto literário dos jovens leitores.

Através do Círculo de leitura, trabalhado por Cosson (2014), embora adaptado para as nossas necessidades frente aos nossos objetivos, pudemos verificar e analisar na prática a 
ideia desenvolvida por Cereja (2004) acerca do "fracasso da escola" em conseguir formar leitores críticos, reflexivos e autônomos ao final do último ano do Ensino Médio.

Diante das análises feitas das reflexões desenvolvidas por um grupo de jovens leitores do último ano do ensino médio, na escola de Referência Albertina da Costa Soares, no bairro de Camela, notamos de modo geral a falta de uma leitura reflexiva mais profunda sobre as personagens, enquanto indivíduos e enquanto uma tríade de causa e efeito. Percebemos, então, que os leitores não exploraram toda a potencialidade da crônica, se detendo a informações explicitas, as quais não exigiam uma leitura atenciosa, ou um leitor proficiente (CEREJA, 2004).

Podemos, igualmente, perceber na brevidade dos argumentos e na estrutura lógica das sentenças dos leitores a falta de hábito em defender um ponto de vista, ou de relacionar a leitura feita à outras anteriores, assim como desenvolver reflexões sobre a construção do texto, percebendo a estilística poética usada pela autora. Embora não desejamos nos ater a forma do texto, devemos considerar que um leitor autônomo, como se propõe a função da escola (BRAZIL, 2006), deveria perceber tais aspectos (tanto interno quanto externo) da construção do texto para auxiliar na construção dos sentidos e ressignificação da obra.

Portanto, de acordo com as análises feitas, acreditamos não apenas faltar aos leitores o hábito ou proficiência na prática da argumentação como em ler e discutir o texto em grupo, assim como fazer interferências/contribuições argumentativas na reflexão do outro. Dessa forma, vimos que além da escolarização (de forma negativa) da atividade do Círculo de leitura ao eleger representante de fala no grupo ao invés de cada leitor compartilhar sua leitura, os jovens "apresentaram para o professor" suas compreensões de forma, também, escolarizada, visto que pareciam estar respondendo - objetivamente - a alguma pergunta feita a priori, quando deveriam estar compartilhando leituras reflexivas e sensações resultantes do contato com o texto literário.

A teoria do fracasso escolar é, conforme Cereja (2004), atribuída, em grande parte, a reprodução, pelo professor de Literatura, de um sistema tecnicista do ensino do conteúdo literário, o qual nega o aluno-leitor enquanto um ser sociopolítico e heterogêneo, impedindo-o de agir sobre o texto e participar ativamente do processo de (res)significação da obra literária. Por conseguinte, temos leituras do texto literário por alunos-leitores no último ano do Ensino Médio que se mantêm na superfície da obra, porque não lhes foram ensinado a mergulharem nas profundezas do texto, como pudemos verificar e analisar nos resultados dessa pesquisa. 
Nesse sentido, essa metodologia reproduzida pelo professor também nega a importância da presença e da leitura do livro/texto em sala de aula, pois o que existe é um resumo de informações sobre a vida do autor, o contexto social e político no qual a obra foi publicada. Acrescentam-se ainda a essa análise superficial do texto literário algumas características referentes à escrita do escritor, as quais o leitor deve localiza-las em um fragmento ou resumo da obra original.

A escolha nossa pelo gênero crônica foi motivada por ser uma escrita que apresenta mais proximidade com a realidade. Portanto, esperávamos que essa escolha pudesse influenciar os leitores a fazer uma ligação entre o conteúdo do texto e a realidade a qual vivemos de modo geral, mas especificamente que houvesse uma leitura subjetiva por cada aluno sobre a crônica.

Para finalizar, é também objetivo dessa pesquisa, após analisar os resultados da recepção do texto literário por leitores em formação no último ano do Ensino Médio, sugerir aos professores de Literatura uma forma mais flexível de trabalhar o texto literário, sendo essa a dinâmica do Círculo de leitura, no qual o aluno passa a ter voz ativa, participando ativamente com sua subjetividade na ressignificação da obra literária. O professor poderá, assim, trabalhar o texto de forma a proporcionar a reflexão através da exposição das leituras feitas pelos alunos durante o Círculo e incentivar questionamentos sobre o tema abordado, o autor, o contexto sociopolítico de antes e o atual, e sobre a obra literária enquanto estrutura a produzir sentidos, caso essas percepções não partam dos leitores. 


\section{REFERÊNCIAS}

ALVES, José Heder Pinheiros. Discutindo alternativas na formação de leitores. In: Memórias da Borborema 4 - discutindo a literatura e seu ensino. Campina Grande: Abralic, 2014. P. $07-18$.

AGAZZI, Giselle Larizzatti. Problemas do ensino da literatura: do perigo ao voo possível. Remate de Males. Campinas-SP, (34.2): pp. 443- 458 , Jul./Dez. 2014.

BARBOSA, Begma Tavares. Letramento literário - sobre a formação escolar do leitor jovem. In. Educ. foco, Juiz de Fora, v. 16, n. 1, p. 145-167. mar. / ago. 2011.

BRASIL, ORIENTAÇÕES CURRICULARES PARA O ENSINO MÉDIO. Linguagens, códigos e suas tecnologias / Secretaria de Educação Básica. - Brasília : Ministério da Educação, Secretaria de Educação Básica, 2006. Disponível em: http://portal.mec.gov.br/seb/arquivos/pdf/03Literatura.pdf. Acesso em 01 de Julho de 2018.

CANDIDO, Antonio. Direito à literatura. Recife: Ed. Universitária da UFPE, 2014. $2^{\mathrm{a}}$ edição.

CEREJA, Willian Roberto. Uma proposta dialógica de ensino de literatura no ensino médio. Tese de doutorado - Pontifícia Universidade Católica, São Paulo, 2004.

COSSON, Rildo. Círculo de leitura e letramento literário. São Paulo: Contexto, 2014.

EAGLETON, Terry. Teoria da literatura: uma introdução. 6. ed. São Paulo: Martins Fontes, 2006.

FREDERICO, Enid Yatsuda e Osakabe, Haquira. Literatura. In Orientações Curriculares do Ensino Médio. Brasília: MEC/SEB/DPPEM, 2004. Acesso em: 01/09/2018 http://portal.mec.gov.br/seb/arquivos/pdf/03Literatura.pdf.

KAHN, Daniela Mercedes. A via crucis do outro: aspecto da identidade e da alteridade na obra de Clarice Lispector. São Paulo, 2000. Acesso em: 03/12/2018. http://www.teses.usp.br/teses/disponiveis/8/8151/tde-03122001-100220/pt-br.php

LANGLADE, Gérard. O sujeito leitor, autor da singularidade da obra. In Leitura subjetiva e ensino de literatura. São Paulo: Alameda, 2013. P. 33.

OLIVEIRA, Ana Arlinda de. O professor como mediador das leituras literárias. In. PAIVA, Aparecida; MACIEL, Francisca; COSSON, Rildo (Org). Literatura: ensino fundamental. Brasília: Ministério da Educação, Secretaria de Educação Básica, 2010. cap. 2.

ROUXEL, Anne. Ensino da literatura: experiência estética e formação do leitor. In. ALVES, José Helder Pinheiros. Memórias da Borborema 4: discutindo a literatura e seu ensino. Campina Grande: Abralic, 2014. p. 19 - 34.

ROSENBAUM, Yudith. A ética na literatura: leitura de "Mineirinho", de Clarice Lispector. Estudos avançados, 2010. Acesso em: 28/11/2018. http://www.scielo.br/pdf/ea/v24n69/v24n69a11.pdf.

SILVA, Ivanda Maria Martins. Literatura em sala de aula: da teoria à prática escolar. Recife: Programa de pós-graduação da UFPE, 2005. 
ZILBERMAN, Regina. Leitura na escola - entre a democratização e o cânone. Literatura em debate, v. 11, n. 21. p. 20-36, jul. 2017.

ZIBERMAN, Regina. A leitura e o ensino da literatura. 1. ed. Curitiba, 2012. Acesso em: 21/08/2018. http://www1.uol.com.br/rionosjornais/rj45.htm 


\section{APÊNDICE:}

\section{Crônica "Mineirinho"}

É, suponho que é em mim, como um dos representantes do nós, que devo procurar por que está doendo a morte de um facínora. E por que é que mais me adianta contar os treze tiros que mataram Mineirinho do que os seus crimes. Perguntei a minha cozinheira o que pensava sobre o assunto. Vi no seu rosto a pequena convulsão de um conflito, o mal-estar de não entender o que se sente, o de precisar trair sensações contraditórias por não saber como harmonizá-las. Fatos irredutíveis, mas revolta irredutível também, a violenta compaixão da revolta. Sentir-se dividido na própria perplexidade diante de não poder esquecer que Mineirinho era perigoso e já matara demais; e, no entanto, nós o queríamos vivo. A cozinheira se fechou um pouco, vendo-me talvez como a justiça que se vinga. Com alguma raiva de mim, que estava mexendo na sua alma, respondeu fria: "O que eu sinto não serve para se dizer. Quem não sabe que Mineirinho era criminoso? Mas tenho certeza de que ele se salvou e já entrou no céu". Respondi-lhe que "mais do que muita gente que não matou". Por que? No entanto a primeira lei, a que protege corpo e vida insubstituíveis, é a de que não matarás. Ela é a minha maior garantia: assim não me matam, porque eu não quero morrer, e assim não me deixam matar, porque ter matado será a escuridão para mim.

Esta é a lei. Mas há alguma coisa que, se me faz ouvir o primeiro e o segundo tiro com um alívio de segurança, no terceiro me deixa alerta, no quarto desassossegada, o quinto e o sexto me cobrem de vergonha, o sétimo e o oitavo eu ouço com o coração batendo de horror, no nono e no décimo minha boca está trêmula, no décimo primeiro digo em espanto o nome de Deus, no décimo segundo chamo meu irmão. O décimo terceiro tiro me assassina - porque eu sou o outro. Porque eu quero ser o outro.

Essa justiça que vela meu sono, eu a repudio, humilhada por precisar dela. Enquanto isso durmo e falsamente me salvo. Nós, os sonsos essenciais.

Para que minha casa funcione, exijo de mim como primeiro dever que eu seja sonsa, que eu não exerça a minha revolta e o meu amor, guardados. Se eu não for sonsa, minha casa estremece. Eu devo ter esquecido que embaixo da casa está o terreno, o chão onde nova casa poderia ser erguida. Enquanto isso dormimos e falsamente nos salvamos.

Até que treze tiros nos acordam, e com horror digo tarde demais - vinte e oito anos depois que Mineirinho nasceu - que ao homem acuado, que a esse não nos matem. Porque sei que ele é o meu erro. E de uma vida inteira, por Deus, o que se salva às vezes é apenas o erro, 
e eu sei que não nos salvaremos enquanto nosso erro não nos for precioso. Meu erro é o meu espelho, onde vejo o que em silêncio eu fiz de um homem. Meu erro é o modo como vi a vida se abrir na sua carne e me espantei, e vi a matéria de vida, placenta e sangue, a lama viva.

Em Mineirinho se rebentou o meu modo de viver. Como não amá-lo, se ele viveu até o décimo-terceiro tiro o que eu dormia? Sua assustada violência. Sua violência inocente - não nas consequiências, mas em si inocente como a de um filho de quem o pai não tomou conta.

Tudo o que nele foi violência é em nós furtivo, e um evita o olhar do outro para não corrermos o risco de nos entendermos. Para que a casa não estremeça.

A violência rebentada em Mineirinho que só outra mão de homem, a mão da esperança, pousando sobre sua cabeça aturdida e doente, poderia aplacar e fazer com que seus olhos surpreendidos se erguessem e enfim se enchessem de lágrimas. Só depois que um homem é encontrado inerte no chão, sem o gorro e sem os sapatos, vejo que esqueci de lhe ter dito: também eu.

Eu não quero esta casa. Quero uma justiça que tivesse dado chance a uma coisa pura e cheia de desamparo em Mineirinho - essa coisa que move montanhas e é a mesma que o fez gostar "feito doido" de uma mulher, e a mesma que o levou a passar por porta tão estreita que dilacera a nudez; é uma coisa que em nós é tão intensa e límpida como uma grama perigosa de radium, essa coisa é um grão de vida que se for pisado se transforma em algo ameaçador em amor pisado; essa coisa, que em Mineirinho se tornou punhal, é a mesma que em mim faz com que eu dê água a outro homem, não porque eu tenha água, mas porque, também eu, sei o que é sede; e também eu, que não me perdi, experimentei a perdição.

A justiça prévia, essa não me envergonharia. Já era tempo de, com ironia ou não, sermos mais divinos; se adivinhamos o que seria a bondade de Deus é porque adivinhamos em nós a bondade, aquela que vê o homem antes de ele ser um doente do crime. Continuo, porém, esperando que Deus seja o pai, quando sei que um homem pode ser o pai de outro homem.

E continuo a morar na casa fraca. Essa casa, cuja porta protetora eu tranco tão bem, essa casa não resistirá à primeira ventania que fará voar pelos ares uma porta trancada. Mas ela está de pé, e Mineirinho viveu por mim a raiva, enquanto eu tive calma.

Foi fuzilado na sua força desorientada, enquanto um deus fabricado no último instante abençoa às pressas a minha maldade organizada e a minha justiça estupidificada: o que sustenta as paredes de minha casa é a certeza de que sempre me justificarei, meus amigos não me justificarão, mas meus inimigos que são os meus cúmplices, esses me cumprimentarão; o 
que me sustenta é saber que sempre fabricarei um deus à imagem do que eu precisar para dormir tranqüila e que outros furtivamente fingirão que estamos todos certos e que nada há a fazer.

Tudo isso, sim, pois somos os sonsos essenciais, baluartes de alguma coisa. E sobretudo procurar não entender.

Porque quem entende desorganiza. Há alguma coisa em nós que desorganizaria tudo uma coisa que entende. Essa coisa que fica muda diante do homem sem o gorro e sem os sapatos, e para tê-los ele roubou e matou; e fica muda diante do São Jorge de ouro e diamantes. Essa alguma coisa muito séria em mim fica ainda mais séria diante do homem metralhado. Essa alguma coisa é o assassino em mim? Não, é desespero em nós. Feito doidos, nós o conhecemos, a esse homem morto onde a grama de radium se incendiara. Mas só feito doidos, e não como sonsos, o conhecemos. É como doido que entro pela vida que tantas vezes não tem porta, e como doido compreendo o que é perigoso compreender, e só como doido é que sinto o amor profundo, aquele que se confirma quando vejo que o radium se irradiará de qualquer modo, se não for pela confiança, pela esperança e pelo amor, então miseravelmente pela doente coragem de destruição. Se eu não fosse doido, eu seria oitocentos policiais com oitocentas metralhadoras, e esta seria a minha honorabilidade.

Até que viesse uma justiça um pouco mais doida. Uma que levasse em conta que todos temos que falar por um homem que se desesperou porque neste a fala humana já falhou, ele já é tão mudo que só o bruto grito desarticulado serve de sinalização.

Uma justiça prévia que se lembrasse de que nossa grande luta é a do medo, e que um homem que mata muito é porque teve muito medo. Sobretudo uma justiça que se olhasse a si própria, e que visse que nós todos, lama viva, somos escuros, e por isso nem mesmo a maldade de um homem pode ser entregue à maldade de outro homem: para que este não possa cometer livre e aprovadamente um crime de fuzilamento.

Uma justiça que não se esqueça de que nós todos somos perigosos, e que na hora em que o justiceiro mata, ele não está mais nos protegendo nem querendo eliminar um criminoso, ele está cometendo o seu crime particular, um longamente guardado. Na hora de matar um criminoso - nesse instante está sendo morto um inocente. Não, não é que eu queira o sublime, nem as coisas que foram se tornando as palavras que me fazem dormir tranqüila, mistura de perdão, de caridade vaga, nós que nos refugiamos no abstrato.

O que eu quero é muito mais áspero e mais difícil: quero o terreno. 